\title{
THE INFLUENCE OF ENVIRONMENTAL MANAGEMENT ACCOUNTING ON FIRM PERFORMANCE WITH GREEN INNOVATION AS AN INTERVENING VARIABLE IN EMPIRICAL STUDIES IN MANUFACTURING COMPANIES
}

\author{
Isabelita Lourdes De Sales \\ Faculty of Economics and Business, University of Airlangga, Indonesia \\ E-mail: isabelitasales27@gmail.com
}

\begin{abstract}
This study aims to measure and analyze the management of the accounting environment for the firm performance with green innovation as an intervening variable. The variables used are environmental management accounting firm performance, green innovation. This study uses secondary data from manufacturing. A total of 101 companies were sampled in this study. The data were analyzed using descriptive statistics, validity and reliability tests using the SPSS 20. The results showed that the accounting management environment was adequate for the performance of companies with green innovation.
\end{abstract}

\section{KEY WORDS}

Environmental management, accounting, firm, performance, green innovation.

Issues regarding the environment are serious problems and need special attention. Every year, global environmental conditions begin to show significant changes. Global warming is one of the negative effects of environmental problems that cannot be avoided. The drastic rise in temperature and uncertain climate change is a threat to survival. Global warming not only triggers weather disruptions, but also results in reduced availability of clean water, disruption to food security, declining quality of public health, and increased intensity of disasters. The problems related to climate change and global warming that is currently being faced are the real impact of the industrial revolution. The industrial revolution is a massive change from an agrarian economy to an industrial economy that uses machinery and fossil fuels in the production process. In the beginning, the industrial revolution was born to increase production significantly and change the economic, political and social life systems in the UK in a better direction. Two centuries after the realization, the industrial revolution proved to bring better changes in the economic, social and political fields in other countries, including Indonesia. Ironically, the increase and expansion of the industrial sector in various countries, including the United Kingdom, is not in harmony with environmental awareness and sensitivity. Three centuries after the realization of the industrial revolution, the negative impact of development and industrial activity on the new environment was felt.

The application of good environmental management accounting in the company will have a lot of impacts on the company, one of which is to increase company performance (saeidi and sofian, 2014). Firm performance is defined as the company's current performance as a whole in the context of product and service quality, employee morale, employee skills, productivity and labor efficiency, and the level of profit that is understood as an increase in overall profits based on sales of products and services ( Thomas B, et al. 2008: 27). In other words, firm performance is the ability of a company to achieve its objectives by using resources efficiently and effectively in accordance with the list statement (2010) in Sosiawani (2015). In the implementation of environmental management accounting has an effect on green product innovation and green process innovation as in the research conducted by Saeidi et al. (2013) concluded that there was a significant positive relationship between the uses of EMA on innovation. The application of Green product and Green process innovation in the company produces various capabilities of the company in gaining competitive advantage; consequently innovation green is considered as an important factor in improving the performance of the company (Saeidi et al., 2013). Environmental issues and pressure from various parties make the company in its production process must pay attention to the 
interests of stakeholders. So in doing green product and green process innovation, companies must pay attention and get support from stakeholders. If the company conducts a green product and green process innovation, it is fully supported by stakeholders, so in the eyes of stakeholders the company has received positive values, and stakeholders will be interested in using the company's products so that the company will benefit. The benefits will automatically improve company performance (De beer and Friend, 2005).

\section{LITERATURE REVIEW}

Environmental Management Accounting, Firm Performance, Green Innovation. The application of a good Environmental Management Accounting in the company will have many impacts on the company, one of which is an increase in company performance (Saeidi and Sofian, 2014). Firm performance is defined as the company's current performance as a whole in the context of product and service quality, employee morale, employee skills, productivity and labor efficiency, and the level of profit that is understood as an increase in overall profits based on sales of products and services ( Thomas B, et al. 2008: 27). In other words, firm performance is the ability of companies to achieve goals by using resources efficiently and effectively in accordance with Daft's statement (2010) in Sosiawani (2015).

Environmental Management Accounting focuses on physical material inputs and outputs that allow managers to assess aspects related to material from the company's environmental performance. Input and output of physical material include waste, emissions, operating materials, equipment efficiency. Information on costs related to the environment that are in the EMA system can help managers manage corporate performance (firm performance) both environmental and economic perspectives (Sirisom and Sonthiprasat, 2011). The application of EMA in companies has a weak positive relationship that is significant with firm performance according to the conclusions of the research conducted by Ramli and Ismail (2013). The application of EMA will help organizations reduce operational costs significantly and will result in large cost savings in addition to increasing company performance and superiority of differentiation can also be achieved (Ramli and Ismail, 2013). Link and Naveh's (2006) study states that the results of the study do not support a positive relationship between EMA and firm performance because there are several companies in Israel that do not yet have an ISO 14001 certificate where the certificate shows the company's attention to environmental issues that lead to improved company performance.

$\mathrm{H} 1$ : Effect of Environmental Management Accounting (EMA) on Company Performance (Firm Performance).

H2: Effect of Environmental Management Accounting on Green Product Innovation.

H3: Effect of Green Process Innovation on Firm Performance.

H4: Effects of Environmental Management Accounting on Firm Performance with Green Product Innovation as a Mediation Variable.

The population companies listed on the Indonesia Stock Exchange in the period 20122016. Sample is 101 manufacturing companies that publish financial reports and annual reports on the IDX website (Indonesia Stock Exchange) from 2012-2016.

Regression models, among others:

$$
\begin{gathered}
\text { Product }=\beta \_1 . \text { EMA }+ \text { e Model } 2 \\
\text { Process }=\beta \_2 . \text { EMA }+ \text { e Model } 3 \\
\text { FP }=\beta \_3 . E M A+\beta \_4 . \text { Product }+\beta \_5 . \text { Process }+e
\end{gathered}
$$

\section{RESULTS OF STUDY}

This research was conducted to find out, test, and prove the influence of environmental management accounting on firm performance with innovation green as an intervening variable. Based on table 1, environmental management accounting (EMA) has the lowest value of -0.4246 and the highest of 0.2755 . Based on the data in appendix 2 , the lowest 
value of EMA is owned by PT Tjiwi Kimia Paper Factory (TKIM) in 2012 and the largest value of EMA is owned by PT Indah Kiatpulp \& Paper (INKP) in 2014. The average EMA owned by the sample is 037828 with a standard deviation of 0.1109585 . This shows the level of distribution of EMA data has a variation level of $-293.32 \%$. The variation level shows that the EMA of the sample company is relatively uniform which means the sample company is still not efficient in managing its environmental accounting management because the average EMA value is still below $50 \%$.

Table 1 - Descriptive Analysis

\begin{tabular}{|c|c|c|c|c|c|}
\hline $\mathrm{n} / \mathrm{n}$ & $\mathrm{N}$ & Minimum & Maximum & Mean & Std. Deviation \\
\hline EMA & 101 & -.4246 & .2755 & -.037828 & .1109585 \\
\hline FP & 101 & -.1560 & .5635 & .087116 & .1107765 \\
\hline PRODUCT & 101 & .0001 & .0084 & .001812 & .0016085 \\
\hline PROCESS & 101 & .0001 & .0167 & .004974 & .0038384 \\
\hline Valid N (listwise) & 101 &
\end{tabular}

Source: Data processed, 2018.

Company performance (FP) has the lowest value of -0.1560 and the highest is 0.5635 . The lowest value of the company's performance is owned by PT Intikeramik Alamsari Industri (IKAI) in 2016 and the company with the highest value is owned by PT Multi Bintang Indonesia (MLBI) in 2016. The average company performance (FP) of all sample companies is 0,087116 with a standard deviation of 0.1107765 . This shows the level of distribution of company performance data has a variation level of $127.16 \%$. The level of variation shows that the performance of companies owned by sample companies is relatively fluctuating, where the company's performance in the sample company exceeds $100 \%$. Fluctuating corporate performance as measured by FP shows that the company's ability to manage company assets to produce relatively different profitability caused by differences in company assets, some has very large amounts of assets and very small assets.

Green product innovation (PRODUCT) has the lowest value of 0.0001 and the highest is 0.0084 . The lowest value of innovation green products is owned by PT Duta Pertiwi Nusantara (DPNS) in 2013, 2014, 2016, PT Indomobil Sukses Internasional (IMAS) in 2013 and 2015, PT Asia Pacific Fibers (POLY) in 2015, and PT Pelangi Indah Canindo (PICO) in 2016. While the highest value is owned by PT Unilever Indonesia (UNVR) in 2013. The average product owned by all sample companies is 0.001812 with a standard deviation of 0.0016085 . This shows that the distribution level of green product innovation data has a variation level of $88.77 \%$. The level of variation shows that the innovation of green product conducted by the sample companies is relatively uniform, where the innovation value of green products in the sample companies is less than $100 \%$. This shows that innovation green products conducted by sample companies are still not optimal in use, seen from the still many companies that obtain minimum values in implementing environmentally friendly product innovations. Green process innovation (PROCESS) has the lowest value of 0.0001 and the highest value is 0.0167 . The lowest value of green process innovation is owned by PT Merek (MERK) in 2014. The highest value is owned by PT Semen Baturaja (SMBR) in 2013. The average process owned by the sample company is 0.004974 and for the standard deviation is 0,0038384 . This results in the level of distribution of green process innovation data having a variation of $77.17 \%$. The level of variation indicates that the green process innovation conducted by the sample companies is relatively uniform, ie less than $100 \%$. This shows that green process innovation conducted by all sample companies is still not optimal, judging from the value of adding a smaller technology burden compared to the total sales from related companies.

Hypothesis 1 Based on the results of multiple linear regression tests it can be concluded that EMA has an effect but not significant on firm performance. This can be seen based on the significance value of the calculation (Sig) of $0.823>$ the confidence level of 0.05 $(5 \%)$.

Based on the EMA regression coefficient value of 0.023 , it can be concluded that EMA 
can improve company performance and have a positive impact on firm performance. Based on the significance value of the calculation and regression coefficient, it can be concluded that EMA has a positive effect on firm performance and proved to be insignificant, so that hypothesis 1 (one) is rejected.

Hypothesis 2 Based on the results of a simple linear regression test it can be concluded that EMA has a significant positive effect on green product innovation. This can be seen based on the significance value of the calculation (Sig) of 0.036 . The calculated significance value is $0.036<0.05(5 \%)$.

EMA regression coefficient value of 0.209 , it can be concluded EMA has a positive impact and can also increase the application of green product innovation (green product innovation). Based on the calculated significance value and regression coefficient, it can be concluded that EMA has a positive effect on green product innovation and proved significant.

Hypothesis testing 3 is the effect of green process innovation on firm performance carried out using multiple linear regression analysis.

Based on the results of multiple linear regression tests it can be concluded that green process innovation has a positive and significant effect on firm performance. This can be seen based on the significance value of the calculation (Sig) of 0.077 . The calculated significance value is $0.077<0.1(10 \%)$.

Green process innovation regression coefficient of 0.178 , it can be concluded that the use of green process innovation (green process innovation) in manufacturing companies has a positive impact on firm performance and can improve company performance. Based on the calculated significance value and regression coefficient value to see the effect of green process innovation on firm performance, it can be concluded that green process innovation has a positive effect on firm performance and proved significant.

Effects of Environmental Management Accounting on Firm Performance with Green Product Innovation as a Mediation Variable

Hypothesis 4: Based on path analysis (path analysis) using the Sobel test shows that green product innovation can mediate the relationship between Environmental Management Accounting (EMA) and firm performance (company performance). Through the results of the Sobel test it can be seen that the indirect effect of EMA on performance firms has a t-count value of 2.018625 , where the $t$-count is greater than the t-table value of 1.983972 (sig. $5 \%$ ). These results are in accordance with Ghozali's statement (2009: 93) where if $t$ count $>t$ table, it can be concluded that there is an indirect influence between EMA on firm performance through green product innovation. Mackinnon et al. (2007) explained that the mediation requirement factor by Baron and Kenny (1986) about the direct influence between the independent variables on the dependent variable must be insignificant as long as the mediation relationship is strong and there is hypothesis 6 (six) which states that green innovation products are able to become a link between the influence of environmental management accounting on firm performance is supported.

\section{CONCLUSION}

Hypothesis 1 (one) states that Environmental Management Accounting (EMA) has a significant positive effect on firm performance. The results of this study indicate that environmental management accounting proved to have a positive but not significant effect on firm performance. This is indicated by the $P$ value of 0.823 which is smaller than $\alpha 0.05(5 \%)$. The results showed that the greater the size of EMA measured by the difference in production costs divided by total sales has a non-significant relationship to the level of company performance (firm performance). This is due to the large number of sample companies experiencing an increase in production costs that have a negative impact because they have to be faced with choices such as reducing the quantity of product sales, increasing product selling prices, and using low-quality raw materials that have a negative impact on the environment. Hypothesis 2 (two) states that Environmental Management Accounting (EMA) has a significant positive effect on green product innovation. The results of this study indicate that environmental management accounting proved to have a significant 
positive effect on green product innovation. This is indicated by the $P$ value of 0.036 which is smaller than a $0.05(5 \%)$. Hypothesis 3 (three) states that Environmental Management Accounting (EMA) has a significant positive effect on green process innovation. The results of this study indicate that environmental management accounting proved to have a significant positive effect on green process innovation. This is indicated by the $P$ value of 0.065 smaller than $\alpha 0.1(10 \%)$. Hypothesis 4 The results of this study indicate that EMA as an information system that leads to improving the performance and quality of business management of companies with innovation as a relevant measure factor for developing ideas, products and processes. Environmental innovation in this case is green innovation products that are very likely to lead to environmental performance and company performance (firm performance). Green product innovation contributes to reducing the environmental burden or the survival target of the company in producing environmentally friendly products that are determined by the legitimacy of society.

\section{REFERENCES}

1. Adialita, Tania. 2014. The Influence of Green Innovation of Japanese Electronic Industries on Competitive Advantage with Particular References to Japanese Home Appliance Industry. Ritsumeikan Asia Pasific University: Business and Administration.

2. Agrestya, Wenty. 2012. Analisis Pengaruh Ukuran Perusahaan and Struktur Modal terhadap Kinerja Keuangan pada Perusahaan Manufaktur yang Terdaftar di BEl. UNISULA.

3. Amabile, T. M. 1996. Creativity in context. Boulder. CO: Westview Press.

4. Aniela, Yoshi. 2012. Peran Akuntansi Lingkungan Dalam Meningkatkan Kinerja Lingkungan and Kinerja Perusahaan. Berkala IImiah Mahasiswa Akuntansi. Vol. 1, No.1.

5. Ar, Ilker Murat. 2012. The Impact of Green Product Innovation on Firm Performance and Competitive Capability: The Moderating Role of Managerial Environmental Concern. Social and Behavioral Sciences, 62:854-864. doi: 10.1016/j.sbspro.2012.09.144.

6. Armstrong, M. 2008. Strategic Human Resource Management, A Guide to Action. London: Kogan Page, (Online), (https://books.google.co.id/books/

7. Azizah, Nurul., Dzulkorim A,R., Endang, Maria Goretti. 2013. Analisis penerapan environmental management accounting (EMA) sebagai bentuk eco-efficiency dalam meningkatkan keunggulan kompetitif perusahaan (Studi pada PT. Perkebunan Nusantara X Unit Usaha Pabrik Gula Ngadirejo Kabupaten Kediri Periode Tahun 2009-2011). Jurnal Administrasi Bisnis. 6:7.

8. Bank Indonesia (BI). 2012. Evaluasi Perekonomian Tahun 2012, Prospek 2013-2014, and Kebijakan Bank Indonesia 2014, and Kebijakan Bank Indonesia, (Online), (09bd3d8b49b24d6abcfd9972122be350TKM_0114.pdf, diakses pada 19 November 2017).

9. Baron, R. M. and Kenny, D. A. 1986. The Moderator-Mediator Variable Distinction in Social Psychological Research: Conceptual, Strategic, and Statistical Considerations. Journal of Personality and Social Psychology, 51(6), 1173-1182.

10. Bartolomeo, Matteo., Bennet, Martin., Bouma, Jan Jaap., Heydkamp, Peter., James, Peter., and Wolters, Teun. 2010. Environmental Management Accounting in Europe: Current Practice and Future Potential. European Accounting Review, 9 (1): 31-52. DOI: 10.1080/096381800407932.

11. Bloom, Nicholas and John Van Reenen, 2002. Patents, Real Options And Firm Performance. The Economic Journal, vol.112: C97-C116.

12. Boedi, S. 2008. Pengungkapan Intellectual Capital and Kapitalisasi Pasar (Studi Empiris pada Perusahaan Publik di Indonesia). Disertasi Doktoral, Universitas Diponegoro.

13. Boughzala, Imed and Jean-Louis Ermine, 2006. Trends in Enterprise Knowledge Management. London. UK: ISTE Ltd. DOI:10.1002/9780470612132.

14. Brown, N. and Deegan, C. 1998. The public disclosure of environmental performance information-a dual test of media agenda setting theory and legitimacy theory. Accounting and Business Research, 29(1): 21-41. DOI: 10.1080/00014788.1998.9729564. 
15. Burlea, Schiopoiu A., Popa I. 2013. Legitimacy Theory. Dalam buku Encyclopedia of Corporate Social Responsibility (ed). SpringerVerlag Berlin Heidelberg: 1579-1584, (Online), (http://www.springerreference.com/docs/html/chapterdbid/333348.html, diakses pada 13 Januari 2018). DOI: 10.1007/978-3-642-28036-8_471.

16. Burritt, R.L., Hahn, T. \& Schaltegger, S. 2002. Towards à comprehensive framework for environmental management accounting - Links between business actors and environmental management accounting tools. Australian Accounting Review,12(2): 3950 .

17. Burrit. R. L. 2004. Environmental Management Accounting: Roadblocks on the Ways To the Green and Pleasant Land. Business Strategy and the Environmental. Vol. 13:13-32. DOI: 10.1002/bse.379.

18. Caracuel, Javier Aguilera and Natalia Ortiz de Mandojana. 2013. Green Innovation and Financial Performance: An Institutional Approach. Organization and Environment SAGE Pub., 26 (4): 365-385. DOI: 10.1177/1086026613507931.

19. Clarkson, P.M., Yue Li, G.D. Richardson, and F.P. Vasvari. 2008. Revisiting the relation between environmental performance and environmental disclosure: An empirical analysis. Accounting, Organizations and Society, Vol. 33: 303-327. doi:10.1016/j.aos.2007.05.003.

20. Chen, Zhilan, Yan, L.C., Aris S., and Anita W.S.W. 2005. Ownership concentration, firm performance, and dividend policy in Hong Kong. Pasific- Basin Finance Journal, 13:431449. doi:10.1016/j.pacfin.2004.12.001.

21. Chen, Yu-Shan, Shyh-Bao Lai, and Chao-Tung Wen. 2006. The Influence of Green Innovation Performance on Corporate Advantage in Taiwan. Journal of Business Ethics, 67:331- 339. DOI 10.1007/s10551-006-9025-5. 